\title{
Study Analysis Fuel from Plastic Waste
}

\author{
Azharuddin $^{1}$, Dwi Arnoldi ${ }^{1}$, Fenoria Putri ${ }^{1}$, Kemas M. Fadhil Almakky ${ }^{1}$, M. Ivan Davala ${ }^{1}$ \\ ${ }^{1}$ Departemen Mechanical Engineering, Politeknik Negeri Sriwijaya, Bukit Besar, Palembang, Indonesia
}

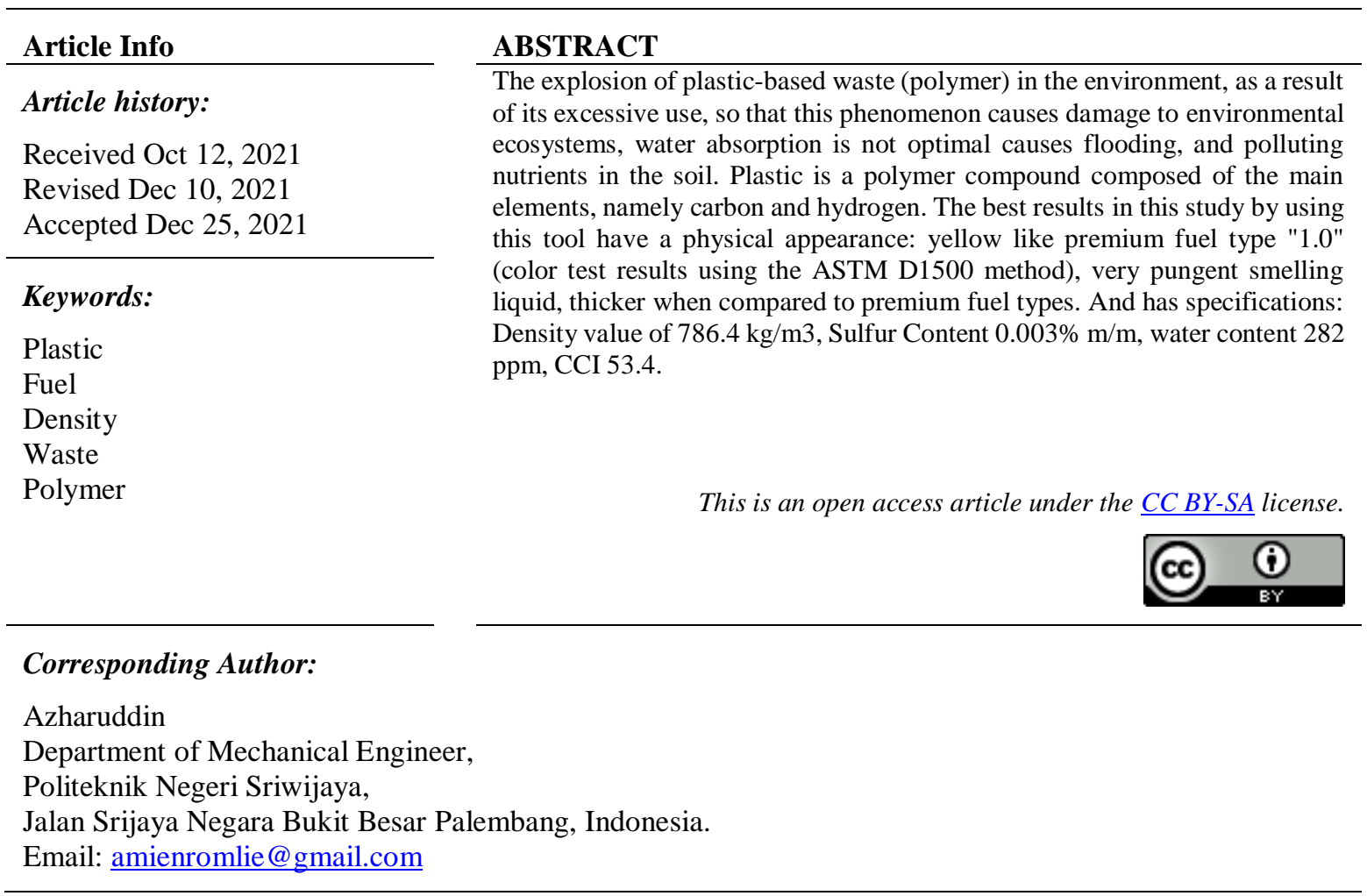

\section{INTRODUCTION}

The explosion of plastic-based waste (polymer) in the environment, as a result of its excessive use, so that this phenomenon causes damage to environmental ecosystems, water absorption is not optimal causes flooding, and polluting nutrients in the soil. There needs to be good management of plastic waste, so the negative impacts arising from this problem can be avoided until it does not harm the community [1].

Pyrolysis is a process that can be used to produce fuel oil from plastic-based materials (polymer). Based on literature review and experimental studies, the fuel produced from this process has physical and chemical properties that are not much different from petroleum (fossil) fuels. In this regard, research on the pyrolysis method is very interesting to do in order to find out how far this method can help the community in overcoming environmental pollution due to plastic waste which has been considered to have no economic value, and can use it as a reference for producing alternative energy sources, in the midst of the increasingly crisis of fossil oil resources [2-4].

One of the efforts that can be made to obtain alternative energy sources to replace fossil fuels is by making or converting energy sources that are around us into alternative fuels that are practical and easy to use. One example is plastic waste as a raw material which is converted into fuel oil through the pyrolysis process. In this pyrolysis process, plastic waste will be decomposed and separated from unnecessary compounds and the fuel contained will be refined to produce fuel oil. 
Plastic is a polymer compound composed of the main elements, namely carbon and hydrogen. If exposed to heat and pressure, materials made of polymeric materials can be made into various shapes according to needs [6-9].

Thermoplastic polymer is one type of polymer that is not resistant to heat. It is very easy to melt and change phase and decompose chemical elements if this type of polymer is heated.

The following are some examples of materials that fall into the category of Thermoplastic Polymers:

1. Polyethylene: Plastic bottles, children's toys, buckets, wire insulators.

2. Polypropylene: Plastic bags, fast food wrappers, cassette boxes, paralon,

3. Polystyrene: Styrofoam

Liquid fuel is a combination of hydrocarbon compounds obtained from nature or artificially (synthesis) with the liquid phase. Liquid fuels are generally processed from petroleum. Along with the times, Liquid fuels that can come from oil shale, coal and biomass are predicted to increase. Crude oil is a naturally occurring mixture of liquid hydrocarbons with small amounts of sulfur, nitrogen, oxygen, and carbon dioxide minerals [5].

Improper waste management will cause bad effects as well, as it is known that plastic is a material that is not easily decomposed by microbes in the soil, although it can take a long time to decompose between 10-15 years, even plastic types. Certain materials can completely decompose after hundreds of years, so that when waste is left in contact with the ground, what happens is that the soil will be polluted and damaged by the chemical compounds contained in plastic. Therefore, instead of leaving plastic as waste, it is better to convert it into alternative fuels. Besides being able to produce alternative fuels, this method can also reduce the volume of plastic waste that pollutes the surrounding environment [9-15 ].

Regarding this problem, then an effort was made to study the method by designing and making a machine for converting plastic waste energy into fuel through the pyrolysis process.

The aim of this research are making a machine for converting renewable energy from plastic waste into fuel oil which optimum, finding out the components needed to make a plastic waste pyrolysis tool into fuel.

\section{RESEARCH METHOD}

\subsection{Detailed Design}

This process is a very important process in making this design. There are two things that must be considered in this design to determine the level of performance of the design to be made, namely: specifications on each component of this tool.

\subsubsection{Examples of designs made:}

Sketch form with Horizontal layout

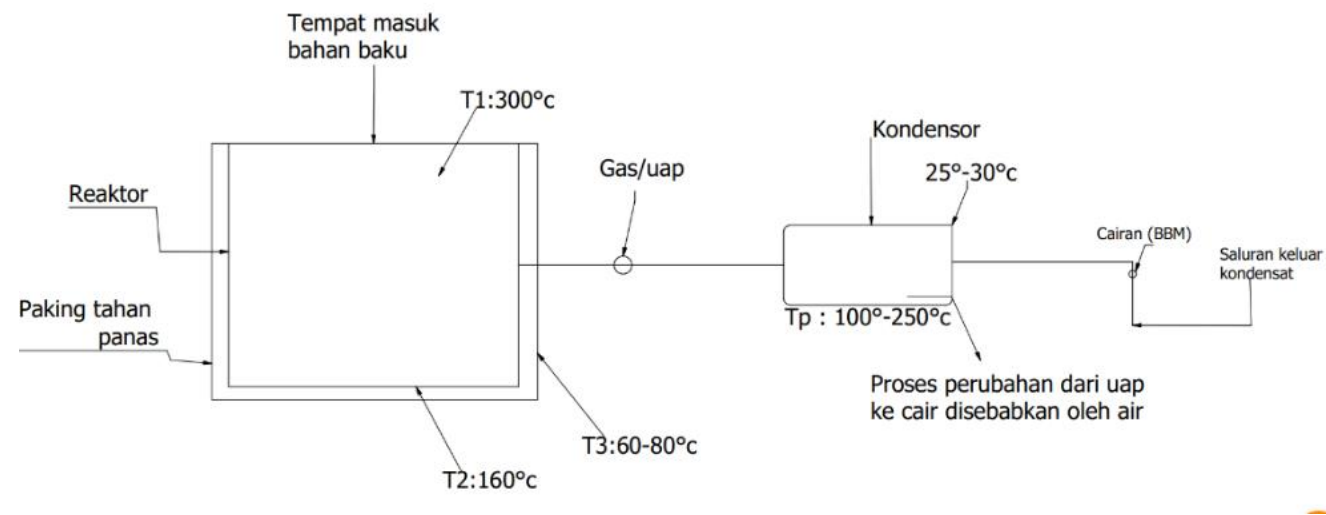

Figure 1 illustration of a design sketch with a horizontal layout)

\subsubsection{Stove}

This stove has a yellow flash point so that the heat generated on the stove used for this design has a maximum heat of $700 \mathrm{oC}$. This stove uses $12 \mathrm{~kg}$ LPG fuel

\subsubsection{Reactor}

The design of the reactor is intended so that the capacity of the reactor can be included as much as 3 $\mathrm{kg}$ of chopped plastic. 
Reactor Tube Specification

Height : $330 \mathrm{~mm}$

Outside Diameter: $305 \mathrm{~mm}$

Inner Diameter : $295 \mathrm{~mm}$

Volumes: ?

Find the reactor volume:

$$
\begin{aligned}
& \mathrm{V}=. \mathrm{r} 2 . \mathrm{T} \ldots \ldots \ldots \ldots \ldots(1) \\
& \mathrm{Rd}=\mathrm{d} / 2(295 / 2=147.5 \mathrm{~mm}) \\
& \mathrm{V}=3.14 .147 .52 .330 \\
& \quad=22543826.25 \mathrm{~mm} 3 \\
& \quad=22543.83 \mathrm{~cm} 3
\end{aligned}
$$

The following is an example of an image showing the flow of heat transfer :

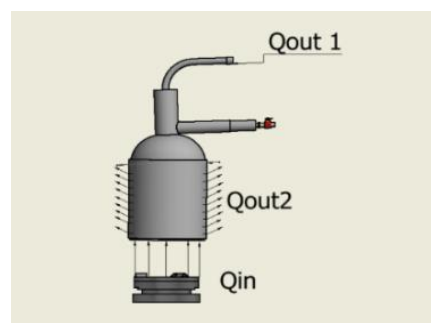

Figure 2 Illustration of heat transfer in the reactor

\subsubsection{Delivery Pipe}

The Pipeline is made Long in order to ease the work of the condenser. The pipe at the exit of the reactor is also insulated so that the steam does not lose heat too quickly because if it loses heat too quickly there will be physical changes in the steam to become like solid wax.

Pipeline Specifications:

Length : $640 \mathrm{~mm}$

Inner Diameter: $21 \mathrm{~mm}$

Outside diameter: $25 \mathrm{~mm}$

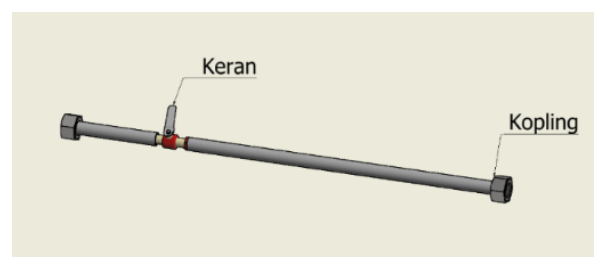

Figure 3 Delivery Pipe

\subsubsection{Condenser}

Condenser Specifications:

The temperature of the steam entering the condenser: $200 \mathrm{oC} * 1$ (the number was chosen to be the temperature of the steam entering the condenser due to the physical change of the polymer from water to gas) Pipe Inner Diameter: $142 \mathrm{~mm}$

Pipe Outside Diameter: $152 \mathrm{~mm}$

Cooling water type: water (H20)

Condenser pipe length: $500 \mathrm{~mm}$

inlet temperature of cooling water: $25 \mathrm{oC}$

outlet temperature of cooling water: $35 \mathrm{oC}$

cooling water flow rate : $0.58 \mathrm{~L} / \mathrm{s} * 2$

Description:

$1:$ this number is chosen to be the temperature of the steam entering the condenser due to the physical change of the polymer from water to gas.

2 : Benchmark on Shimizu Pump Specifications 
2.2 Research Procedure

1. Prepare shredded plastic that has been cleaned and weighed with the specified weight.

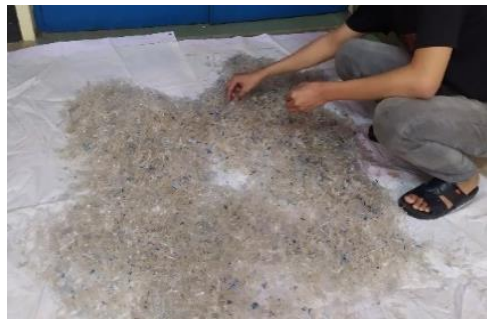

Figure 4. Preparation of Raw Materials for Testing Tools

2. Open the reactor lid, and put the raw materials into the reactor, then coat the lid and the reactor tube with a heat-resistant gasket, then close the lid and lock it back tightly.

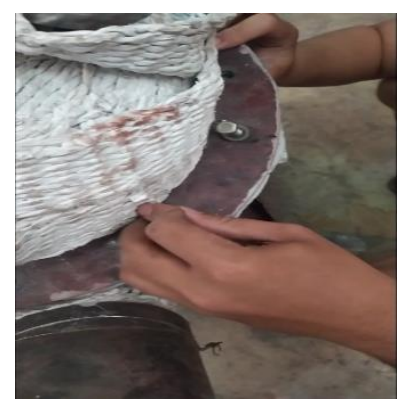

Figure 5 Tightly Locking the Reactor Tube

3. Connect the reactor with the condenser using the gas outlet

4. Ensure that the Reactor Tube and Cap and the Connecting Pipe to the Condenser are installed very tightly so that there is no leakage.

5. Install the regulator on the gas cylinder (LPG).

6. Fully fill the water drum and start the pump on the condenser.

7. Install the Pressure gauge and Hot Pressure on the projector cover, then run it at the same time as the stove is turned on.

8. Let the process take place and record each reaction for the specified time (+- 2 Hours).

9. After 2 hours, the testing process is declared complete. Turn off each test circuit, starting from the stove, pump, etc. Then record neatly, what has been recorded when the testing process takes place.

\subsection{Analysis Procedure}

\subsubsection{Density Analysis}

a) The sample is put into a $500 \mathrm{ml}$ measuring cup.

b) The hydrometer is inserted with the appropriate scale into the measuring cup until the hydrometer floats and record the value on the surface of the product in the measuring cup marked on the hydrometer.

c) The thermometer (Fahrenheit units) is inserted into the measuring cup and recorded the temperature.

d) The numbers listed on the hydrometer and temperature are converted to the Specific Gravity conversion that has been made by ASTM D-1298 and the density is calculated by the following formula.

$$
\text { Densitas }(p)=(\text { Specific Gravity }-0,0003) \times 1000 \mathrm{Kg} \mathrm{m}^{3}
$$

\subsubsection{Analysis of Fuel Composition Using ASTM D-86 . Distillation}

(1) The sample is measured $100 \mathrm{ml}$ using a measuring cup.

(2) The sample is put into a $100 \mathrm{ml}$ distillation flask to which a thermometer has been added (in Celsius) and then connected to the instrument.

(3) The distillation apparatus is turned on under appropriate operating conditions. 
(4) The temperature of the first drop of distillation is recorded which is called the Initial Boiling Point (IBP).

(5) The temperature of the distillation result is recorded in every $10 \mathrm{ml}$ volume of the measuring cup.

(6) The temperature of the last drop of distillation is recorded which is called the Final Boiling Point (FBP).

(7) The amount of residue and losses is calculated from the amount of product that is not evaporated by the tool after FBP.

\subsubsection{Analysis}

The calculated cetane number or the Calculated Cetane Index (CCI) is calculated by the ASTM D4737 method with the following formula.

$$
\begin{array}{rl}
\mathrm{CCI}=4 & 45,2+(0,0892)\left(\mathrm{T}_{10 \mathrm{~N}}\right)+(0,131+(0,901)(\mathrm{B}))\left(\mathrm{T}_{50 \mathrm{~N}}\right)+ \\
& (0,0523-(0,420)(\mathrm{B}))\left(\mathrm{T}_{90 \mathrm{~N}}\right)+(0,00049)\left(\left(\mathrm{T}_{10 \mathrm{~N}}\right)^{2}-\left(\mathrm{T}_{90 \mathrm{~N}}\right)^{2}\right)+ \\
& (107)(\mathrm{B})+(60)(\mathrm{B})
\end{array}
$$

$\mathrm{D}=$ Density in ASTM D-1298 $(\mathrm{Kg} / \mathrm{m} \neg 3)$

$\mathrm{DN}=\mathrm{D}-0.85$

$\mathrm{B}=(\mathrm{e}(\mathrm{DN})(-3,5) \neg)-1$

T10 $=$ Temperature at $10 \%$ vol in ASTM D-86 distillation $\left({ }^{\circ} \mathrm{C}\right)$

$\mathrm{T} 10 \mathrm{~N}=\mathrm{T} 10-215$

T50 = Temperature at 50\%vol in ASTM D-86 distillation $\left({ }^{\circ} \mathrm{C}\right)$

$\mathrm{T} 50 \mathrm{~N}=\mathrm{T} 50-260$

T90 = Temperature at 90\% vol in ASTM D-86 distillation $\left({ }^{\circ} \mathrm{C}\right)$

$\mathrm{T} 90 \mathrm{~N}=\mathrm{T} 50-310$

\section{RESULTS AND DISCUSSION}

After conducting the trial, the authors conducted an analysis of the data that had been obtained, the following are the results of the analysis:

Overall, every component in the circuit works quite well, the stove can heat the reactor to the highest temperature of up to $300^{\circ} \mathrm{C}$ with consistent fuel consumption, the condenser, which is a heat exchanger, functions quite well. This can be seen from the average temperature of the steam entering and leaving the condenser which has decreased significantly.

From the results of the test 3 times using plastic raw materials that have been chopped, it produces $678 \mathrm{ml}$ of liquid oil, with the characteristics:

A. Yellow liquid like premium type of fuel, this is in accordance with the results of the color test using the ASTM D1500 method which shows a value of 1.0

B. The liquid smells very pungent

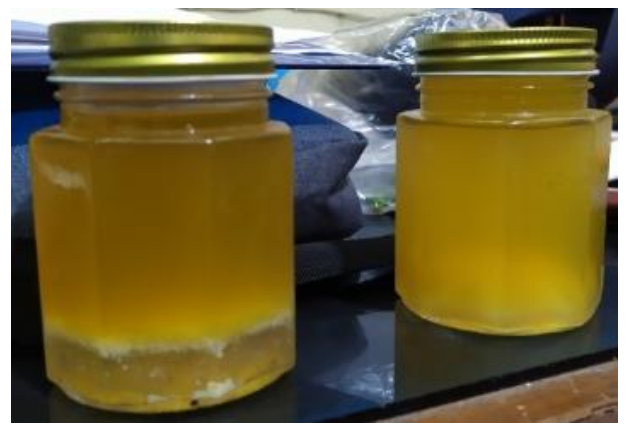

Figure 6 Products produced 
C. Liquid burns when ignited with fire
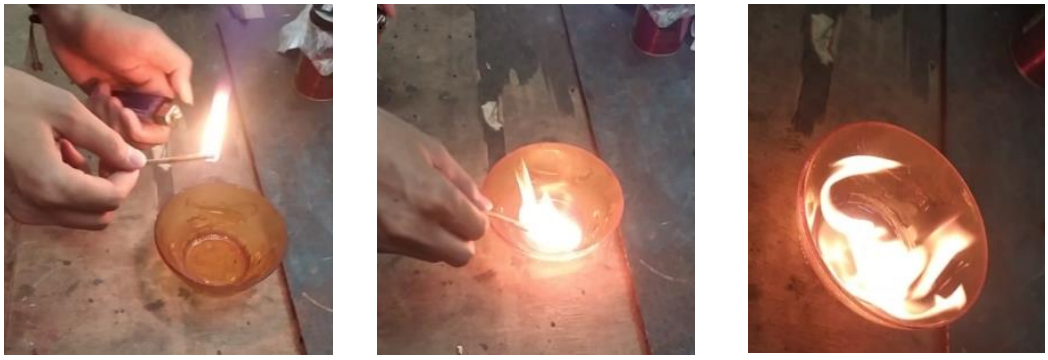

Figure 7. Product Liquids ignited with fire

C. The resulting liquid is more viscous when compared to premium types of fuel.

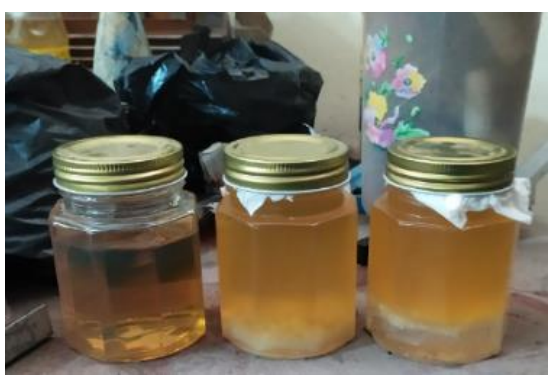

Figure 8 . Results of the $1 \mathrm{st}-3$ rd Trial Products

E. Liquids can freeze when stored at room temperature

Table 1. Density Analysis Results

\begin{tabular}{ccc}
\hline \multicolumn{3}{c}{ Oil Density $\left(\mathrm{Kg} / \mathrm{m}^{3}\right)$} \\
\hline Oil A & 786.4 \\
Oil B & 788,4 \\
\hline
\end{tabular}

Based on the following table, Oils A and B have a tendency to be classified as gasoline fraction specifications, namely $715-770 \mathrm{~kg} / \mathrm{m} 3$. Density analysis of this product uses the ASTM D1298 method. The density value of the product is more likely to exceed the specification limit of pure gasoline because there is still an oil fraction that is heavier than gasoline so that the density value of this product is higher than the specification of pure gasoline.

Table 2. Results of Distillation Analysis

\begin{tabular}{ccc}
\hline Distillation & Oil A $\left({ }^{\circ} \mathrm{C}\right)$ & Oil B $\left({ }^{\circ} \mathrm{C}\right)$ \\
\hline Initial Boiling Point & 90 & 98 \\
$10 \% \operatorname{Vol~Rec}^{\circ} \mathrm{C}$ & 135 & 133 \\
$20 \% \operatorname{Vol~Rec}^{\circ} \mathrm{C}$ & 148 & 148 \\
$30 \% \operatorname{Vol~Rec}^{\circ} \mathrm{C}$ & 164 & 162 \\
$40 \% \operatorname{Vol~Rec}^{\circ} \mathrm{C}$ & 183 & 181 \\
$50 \% \operatorname{Vol~Rec}^{\circ} \mathrm{C}$ & 213 & 210 \\
$60 \% \operatorname{Vol~Rec~}^{\circ} \mathrm{C}$ & 246 & 231 \\
$70 \% \operatorname{Vol~Rec}^{\circ} \mathrm{C}$ & 279 & 253 \\
$80 \% \operatorname{Vol~Rec}^{\circ} \mathrm{C}$ & 302 & 287 \\
$80 \% \operatorname{Vol~Rec}^{\circ} \mathrm{C}$ & 340 & 338 \\
Final Boiling Point & 354 & 352 \\
Residue + Loss & 4 & 5 \\
\hline
\end{tabular}

The distillation analysis of this product was carried out using the ASTM D86 method. The resulting product has a tendency to belong to the diesel fraction which has been standardized by Pertamina. The following table shows that in distillation this product has the highest boiling point (end point) at $354 \mathrm{oC}$ in oil $\mathrm{A}$ and $352 \mathrm{oC}$ in oil $\mathrm{B}$. This happens because this product does not Purification is carried out based on one of the fractions so that this product is classified as a mixed (heterogenic) fraction between gasoline and diesel. 


\begin{tabular}{ccc}
\multicolumn{2}{c}{ Table 3. Results of Sulfur Content Analysis } \\
\hline \multicolumn{3}{c}{ Sulfur Content $(\% \mathrm{~m} / \mathrm{m})$} \\
\hline Oil A & 0.003 \\
Oil & 0,0062 \\
\hline
\end{tabular}

Analysis of sulfur content in this product using the ASTM D-4294 method. This product shows that the sulfur content of A and B oils is classified as being able to be used as a commercially viable fuel. This is because the sulfur content of oil $\mathrm{A}$ is below the maximum sulfur content limit, which is below $0.005 \% \mathrm{~m} / \mathrm{m}$. while oil B has a higher sulfur content than oil A and tends to be below the maximum sulfur content of pure gasoline products standardized by Pertamina, which is $0.05 \% \mathrm{~m} / \mathrm{m}$.

Table 4. Results of Water Content Analysis

\begin{tabular}{cc}
\hline \multicolumn{3}{c}{ Water Content $(\mathrm{ppm})$} \\
\hline Oil A & 282 \\
Oil B & 314 \\
\hline
\end{tabular}

Analysis of the water content in this product using the ASTM D-6304 method. Based on the following table, the water content in oil A and oil B is below the maximum water content of diesel fuel, which is 500 $\mathrm{ppm}$. This shows that these two products are worthy of being used as fuels that are commercially viable and safe to use.

Table 5. CCI Analisa Analysis Results

\begin{tabular}{ccc}
\hline & Calculated Cetane Index (CCI) \\
\hline Oil A & 53.4 \\
Oil B & 51,8 \\
\hline
\end{tabular}

The cetane number in this product is based on the ASTM D-4737 test method. This method is called the Calculated Cetane Index (CCI). CCI calculations are based on ASTM D-1298 density data and ASTM D86 distillation. The calculated cetane number is matched with the standard specification for the cetane number in diesel fuel, which is at least 45 (Pertamina, 2016). The cetane number is calculated in this product because the mixture has a diesel fraction so the calculation of the octane number is not needed. This was proven when the ASTM D-86 distillation test was carried out on this product which showed that the last drop at the end of the product distillation stated by the Final Boiling Point (FBP) was within specifications outside gasoline or motor gasoline (above $200^{\circ} \mathrm{C}$ ).

The effect of the cetane number in diesel products is that the higher the cetane number, the better the quality of diesel fuel obtained. Diesel fuel with a high cetane number will have a shorter ignition period than fuel with a lower cetane number (Dharma, et al, 2018). Based on the CCI analysis, Oil A and Oil B meet the criteria for diesel fuel based on the specified diesel fuel specifications.

\section{CONCLUSION}

Every component in the circuit works quite well. This tool is capable of operating at a maximum temperature of $300^{\circ} \mathrm{C}$ to convert plastic into fuel oil. With 3 trials can produce 2 products (Oil A) Clear Oil, (Oil B) slightly cloudy oil.

The best results obtained using this tool have a physical appearance: yellow like premium fuel type "1.0" (color test results using the ASTM D1500 method), very pungent smelling liquid, thicker when compared to premium fuel types. And has specifications: Density value of $786.4 \mathrm{~kg} / \mathrm{m} 3$, Sulfur Content $0.003 \% \mathrm{~m} / \mathrm{m}$, water content 282 ppm, CCI 53.4.

\section{ACKNOWLEDGEMENTS}

The authors would like to thank the Ministry of Cultural and Education of Republic of Indonesia, Directoral of Vocational Higher Education, Politeknik Negeri Sriwijaya through KERDOSMA Scheme. 


\section{REFERENCES}

[1] T. Adharsyah, "Sebegini Parah Ternyata Masalah Sampah Plastik Di Indonesia", www.cnbcindonesia.com.me//www.cnbeindonesia.com/lifestyle/20190721140139-33-S6420/sebeginiparah-ternyata-masalah-sampah-plastik-di Indonesia._2019, retrieved March 19, 2020.

[2] Website "Pengolahan Sampah Plastik Menjadi Bahan Bakar", ilmugeografi.com.https://Ilmugeografi.com/ilmu-sosial/pengolahan- sampah-plastik., retrieved March 19,2020 .

[3] Kiki,. "Plastik Dan Tantangan Problem Lingkungan ke Depan." www.kanalkalimantan.com.https://www.kanalkalimantan.com/plastik-lan tantangan-problemlingkungan-ke-depan. 2019, retrieved March,19 2020

[4] Kompasiana.com. "Limbah Sampah Plastik Sebagai Sumber Energi Terbarukan Menjadi Bensin."www.kompasiana.com.https://www.kompasiana.com// didikarwinsyah.blogspot.com/59c53fa8da14194158419b24/limbah-sampah-plastik-sebagi-sumber-energiterbarukan. 2017. retrieved March 19, 2020.

[5] Novita, D. Marya, and E. Damanhuri.. "Perhitungan Nilai Kalor Berdasarkan Komposisi Dan Karakteristik Sampah Perkotaan Di Indonesia Dalam Konsep Waste To Energy." Jurnal Teknik Lingkungan Vol: 16 No.2: p. 103-14. 2009.

[6] Website sharingconten.com. "Pengertian Plastik Terlengkap Beserta Penjelasan, Manfaat, Dan Jenisnya."www.sharingconten.com.https://sharingconten.com/pengertian-plastik-dan-manfaat-plastik, retrieved (March 19, Kreatif Untuk Mengatasi 2020).

[7] M Kamal, F. Arifin, Rusdianasari, "Analysis of the Performance of The Four-Blade Darrieus Wind Turbine at the Jamik Bukit Asam Mosque Complex Tanjung Enim South Sumatra", International Journal of Research in Vocational Studies (IJRVOCAS), Print ISSN 2777-0168, Online ISSN 2777-0141, Vol 1, No.2, 2021, DOI: https://doi.org/10.53893/ijrvocas.v1i2.52

[8] O. Irawan, Y. Bow, R.D. Kusumanto,"Simulation and Performance Test Giromill Type Wind Turbine; Case Study Muara Enim, South Sumatra, Indonesia ", International Journal of Research in Vocational Studies (IJRVOCAS), Print ISSN 2777-0168, Online ISSN 2777-0141,Vol. 1, No.2, 2021, DOI: https://doi.org/10.53893/ijrvocas.v1i2.10

[9] B. Irawan, Rusdianasari, A. Hasan, "Pyrolysis Process of Fatty Acid Methyl Ester (FAME) Conversion into Biodiesel", International Journal of Research in Vocational Studies (IJRVOCAS), Print ISSN 27770168, Online ISSN 2777-0141, Vol 1., No.2, 2021, DOI: https://doi.org/10.53893/ijrvocas.v1i2.21

[10] Julismi, Rusdiana, A. Hasan, "Syngas Underground Coal Gasification (UCG) Testing of In-Situ Type Lignite Coal and Fracture Type Coal", International Journal of Research in Vocational Studies (IJRVOCAS), Print ISSN 2777-0168, Online ISSN 2777-0141, ,Vol.1, No. 2, 2021 DOI: https://doi.org/10.53893/ijrvocas.v1i2.42

[11] Wiratmaja, I.. "Pengujian Karakteristik Fisika Biogasoline Sebagai Bahan Bakar Alternatif Pengganti Bensin Murni". Jurnal Ilmiah Teknik Mesin Tanggal 2 Juli 2019. Cakra. Vol. 4(2): 145-154. 2010.

[12] Suminto, Sekartaji. "Ecobrick: Solusi Cerdas Dan Sampah Plastik." PRODUCTUM Jurnal Desain Produk (Pengetahuan dan Perancangan Produk) 3(1): 26., 2017

[13] Direktorat Jenderal Minyak dan Gas Bumi. 2013. Standar dan Mutu Bahan Bakar Minyak Jenis Bensin 88 yang Dipasarkan Dalam Negeri No. 933.K/10/DJM.S/2013. Jakarta: Kementerian Energi dan Sumber Daya Mineral Republik Indonesia.

[14] Direktorat Jenderal Minyak dan Gas Bumi. 2016. Standar dan Mutu Bahan Bakar

[15] Minyak Jenis Solar yang Dipasarkan Dalam Negeri No.28.K/10/DJM.T/2016. Jakarta: Kementerian Energi dan Sumber Daya 


\section{BIOGRAPHIES OF AUTHORS}
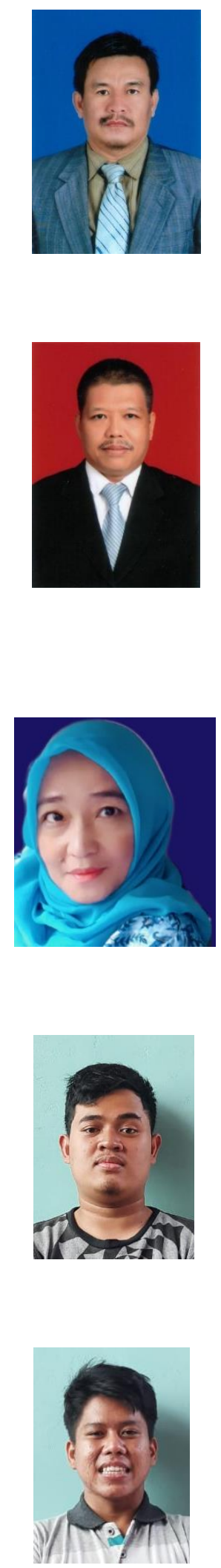

H. Azharuddin, ST., MT. is a Lecturer in Mechanical Engineering Department, Politeknik Negeri Sriwijaya He is interested in conversion energy, manufacturing, and fuel cell. Some articles have written by him in international conference and journal. He is doing in renewable field.

Dwi Arnoldi, ST. MT., is a Lecturer in Mechanical Engineering Department, Politeknik Negeri Sriwijaya He is interested in hydraulic and pneumatic, manufacturing, and Electrical. Some articles have written by him in international conference and journal. He is doing in mechanical testing material.

Fenoria Putri, ST. MT., is a Lecturer in Mechanical Engineering Department, Politeknik Negeri Sriwijaya She is interested in material science, production processing, and welding area. Some articles have written by him in international conference and journal. She is doing in advance material.

Kemas M. Fadhil Almakky is student advance diploma (DIV) in Mechanical Engineering Department, Politeknik Negeri Sriwijaya $\mathrm{He}$ is interested in material science, production processing, and conversion energy. He is doing his project for finishing his degree.

M. Ivan Davala is student advance diploma (DIV) in Mechanical Engineering Department, Politeknik Negeri Sriwijaya He is interested in material science, production processing, and design manufacture. He is doing his project for finishing his degree. 